\title{
The impact of packaging on product competition
}

\author{
Naser Azad ${ }^{\mathrm{a}}$ and Maryam Masoumi ${ }^{\mathbf{b}^{*}}$
}

${ }^{a}$ Department of Management, Islamic Azad University, South Tehran Branch, Tehran, Iran

${ }^{b}$ Department of Management, Islamic Azad University, Arak Branch, Arak, Iran

\begin{tabular}{|c|c|}
\hline A R T I C L E I N F O & A B S T RAC T \\
\hline $\begin{array}{l}\text { Article history: } \\
\text { Received August 25, } 2012 \\
\text { Received in revised format } \\
\text { 25 September } 2012 \\
\text { Accepted } 4 \text { October } 2012 \\
\text { Available online } \\
\text { October } 62012 \\
\text { Keywords: } \\
\text { Marketing } \\
\text { Packaging } \\
\text { Competition }\end{array}$ & $\begin{array}{l}\text { The primary objective of this paper is to detect important factors, which are influencing } \\
\text { competitive advantage. The proposed model of this paper uses sampling technique to measure } \\
\text { characteristics of society. There are eight independent variables for the proposed study of this } \\
\text { paper including packaging endurance, easy distribution, customer promotion through } \\
\text { packaging, packaging structure, packaging as silent advertiser, diversity of packaging, clean } \\
\text { and healthy packaging and innovation in packaging. The proposed study uses structural } \\
\text { equation modeling to either accept or reject all hypotheses associated with the proposed study } \\
\text { of this paper. The population of this study includes all managers and experts who are involved } \\
\text { in packaging products. We used simple sampling technique and chooses } 300 \text { from a population } \\
\text { of } 450 \text { people who are considered as the population of this survey. Cronbach alpha was } \\
\text { determined as } 0.732 \text {, which is above the minimum acceptable level. The results confirm that all } \\
\text { mentioned factors influence competitiveness, effectively. }\end{array}$ \\
\hline
\end{tabular}

\section{Introduction}

Packaging is one of the most important parts of marketing planning and it plays a key role on marketing products and services. A good packaging absorbs more customers and increases people's intention on purchasing products. Nowadays, consumers today are faced with many demands because of an increase in consumers' income. Producers also need to make appropriate changes on their strategies to meet customers' requirements and compete with new competitors. Innovation in new products are important factors for improving efficiency and effectiveness (Noorani \& Setty, 2007). Packaging is one of the most important techniques to increase the success in business strategies. Packaging plays a key role in product development since it is part of product and it could impact all products' characteristics (Olsson et al., 2004).

* Corresponding author.

E-mail addresses: ma.masumi@yahoo,com (M. Masumi) 
For years, packaging was one important factor in building appropriate market (Silayoi \& Speece, 2004; Silayoi \& Speece, 2007). One primary question is known the relationship between packaging characteristics and competition. When a particular product is located in showcase of supermarkets with attractive image, more customers are expected to be attracted. In most cases, customers purchase the products mostly because of the package and not based on product's characteristics. Packaging can be accomplished through different methods such as paper packaging, plastic, glass, etc. Size and color play important role in packaging and packaging graphical characteristics such as color type are important factors (Rundh, 2009).

Other important characteristic is associated with shape and structure of packaging products since design of a product could influence purchasing product as well. This has motivated many design makers to concentrate on products shape and structure (Raghubir \& Greenleaf, 2006). A good packaging must contain all necessary information required by customers on a label shown on the product and this is a good way to express producers' concern on benefit of using products (Wells et al., 2007).

Packaging needs to identify product characteristics pretty well and there must be an instruction for use on products. There must be a fast and reliable way for communicating with customers from the labels on the products. The more information on the packaging, the more customer satisfaction from the product we can expect. The other necessary requirement is to provide the necessary information of the producer. Customers normally have less time to make their choices and products must find a suitable way to get necessary information as quickly as possible (Ahmed et al., 2005). There are two information factors in any products, which must be considered. First information factors such as RFID, label, etc. and second other necessary information, which are provided in separate paper, etc. However, when there are too many environmental or governmental issues, customers may get confused. Therefore, products must contain the least but the most important information (Yang \& Priya, 2005).

Butkevičiené et al. (2008) discussed the impact of consumer packaging communication on consumer decision making process. The results of their empirical research confirmed that theoretical package communication must contain the effect of package form and size in the stage of need perception. The effect of the package graphics, special offers and package ecology communication need to be marked as less important in the stage of alternatives' assessment in the model.

Borin et al. (2011) performed an investigation on the effect of various levels of environmental information on key consumer metrics and evaluated environmentally benign products versus those that have negative environmental impacts. They reported that consumer perception of product quality, value, and purchase intentions did not differ substantially between products with positive environmental messages and those with no message. Products with positive environmental messages were considered better than products with negative environmental messages.

They also reported that the effect of environmental information was greater for consumable products. Marsh and Bugusu (2007) discussed that the primary aim of food packaging must be to maintain the safety, wholesomeness, and quality of food. The effect of packaging waste on the environment can be reduced by prudently selecting materials, following EPA guidelines, and reviewing expectations of packaging in terms of environmental effect. Knowledgeable attempts by industry, government, and consumers can promote continued improvement, and an understanding of the functional 
characteristics of packaging will reduce much of the well-intentioned but ill-advised solutions, which would not sufficiently account for both preconsumer and postconsumer packaging items. Logistics can also be considered as another important factor for improving packaging products.

Hellström and Nilsson (2011), for instance, investigated logistics-driven packaging innovation: a case study at IKEA. Rundh (2005) explained the Multi-faceted dimension of packaging and tried to provide good guidelines for making a selection between marketing logistic and marketing tool. The other issue in packaging is associated with ethical issues (Boyce et al., 2008). Vernuccio et al. (2011) presented an exploratory study of marketing, logistics, and ethics in packaging innovation. Design is another perspective in packaging product and many believe that packaging of a product must start from early stage in design part (Wansink, 1996; Lee \& Lye, 2003; Howard \& Moskowitz, 2010). Ampuero and Vila (2006) discussed the need to understand consumer perceptions in order to properly design product packing and to reach the desired position in the minds of consumers. They reported that each positioning strategy appears associated with particular packaging dimensions.

Azad et al. (2012) investigated the relations between packaging food products produced for children and parents' willingness to buy these kinds of products. They used a questionnaire based on Likert scale, distributed among 392 people and collected 381 filled questionnaires. There were three hypotheses: The first hypothesis assumed there was a meaningful relationship between packaging children's food characteristics and parents' intention on purchasing product. The second hypothesis studied the relationship between children food packaging and the parent's priority purchasing decision and the third hypotheses examined the relationship between children food selection and the parent's purchasing decision. The results confirmed all three hypotheses and provided some evidences that a suitable packaging for children's food product played important role on parents' intention for purchasing products. Azad et al. (2012), in another work, used a questionnaire-based survey to find the most important factors influencing advertisement. They focused on gathering information from the advertisement providers to assess each advertisement plan.

\section{The proposed method}

The primary objective of this paper is to detect important factors, which are influencing competitive advantage. The proposed model of this paper uses sampling technique to measure characteristics of society. There are eight independent variables for the proposed study of this paper including packaging endurance (HEFAZAT), easy distribution (TOZIE), customer promotion through packaging (TARFI), packaging structure (SAKHTAR), packaging as silent advertiser (BASTE), diversity of packaging (TANAVO), clean and healthy packaging (SALAMATI) and innovation in packaging (NOAVARI). The proposed study uses structural equation modeling to either accept or reject all hypotheses associated with the proposed study of this paper. The population of this study includes all managers and experts who are involved in packaging products. We used simple sampling technique and chooses 300 from a population of 450 people who are considered as the population of this survey. Cronbach alpha was determined as 0.732 , which is above the minimum acceptable level.

\section{The results}

The proposed study of this paper uses and t-student to verify all hypotheses. Fig. 1 and Fig. 2 show details of the implementation of LIREL software package. In addition Table 1 presents a summary of 
the results. As we can observe from the results of Table 1, one gamma is assumed to be one to set a base for comparing other gammas with this parameter.

\section{Table 1}

The summary of the gammas and t-student values

\begin{tabular}{rrrrrrrrrrrrrrrrr}
\hline & 1 & 2 & 3 & 4 & 5 & 6 & \multicolumn{1}{c}{8} & \multicolumn{1}{c}{9} & \multicolumn{1}{c}{10} & \multicolumn{1}{c}{12} & 13 & $\mathrm{X}_{1}$ & $\mathrm{X}_{3}$ \\
\hline $\mathrm{B}$ & 1.00 & 0.96 & 0.73 & 1.00 & 0.96 & 0.86 & 1.00 & 1.21 & 1.39 & 1.00 & 0.90 & 0.96 & 0.90 & 1 & 1.02 \\
$\mathrm{~T}$ & - & 12.74 & 10.65 & - & 9.77 & 8.87 & - & 9.61 & 10.82 & - & 10.28 & 10.63 & 10.32 & - & 13.07 \\
\hline & 14 & 15 & 16 & 17 & 18 & 19 & 20 & 21 & 22 & 23 & 24 & 25 & 26 & $\mathrm{X}_{2}$ & \\
\hline $\mathrm{B}$ & 0.50 & 1 & 1.03 & 0.92 & 1.00 & 0.67 & 1.64 & 1.00 & 1.11 & 0.93 & 1.00 & 1.04 & 0.83 & 1.3 & \\
$\mathrm{~T}$ & 5.22 & - & 0.92 & 9.33 & - & 5.14 & 7.36 & - & 6.87 & 6.17 & - & 8.44 & 7.56 & 15.6 \\
\hline
\end{tabular}
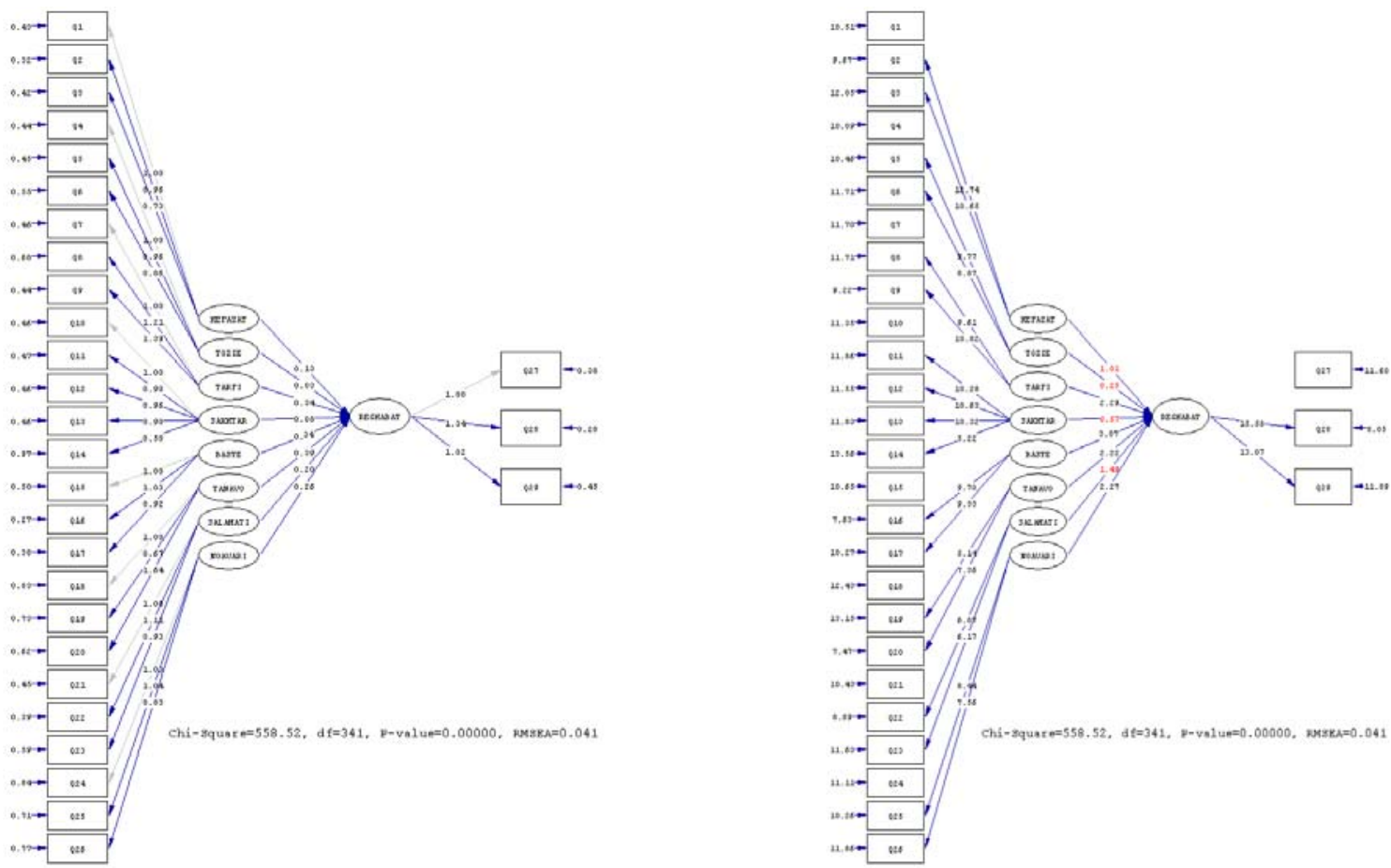

Fig. 1. The coefficient of each eight items

Fig. 2. t-student values of coefficient

Based on the results of Table 1, all coefficients are statistically meaningful. In addition, Chi-square is equal to 558.52 with P-value of 0.0000 and RMSEA=0.041. These results confirm the validity of our results. Based on the results of survey, we can conclude that in order to increase competition, we need to increase packaging endurance and facilities distribution process to provide ease of access for customers. Packaging must be used to promote sales' figures and it must capture customers' eyes in just a few moments. The other important factor is the structure of packaging infrastructure and a product with good packaging characteristics is in fact a good missioner for advertisement of the product. Finally, clean and healthy packaging as well as innovative packaging could also contribute to product development.

\section{Conclusion}

We have performed an empirical study to determine important factors influencing competitive advantage including packaging endurance, easy distribution, customer promotion through packaging, 
packaging structure, packaging as silent advertiser, diversity of packaging, clean and healthy packaging and innovation in packaging. The proposed study used structural equation modeling to either accept or reject all hypotheses associated with the proposed study of this paper. The results confirm that all mentioned factors influence competitiveness, effectively. In summary, we can conclude that it is important to look into different factors influencing marketing activities and find out possible alternatives for better penetrating into market.

\section{Acknowledgment}

The authors would like to thank the anonymous referees for constructive comments on earlier version of this work, which contributed, significantly.

\section{References}

Ahmed, A., Ahmed, N., \& Salman, A. (2005). Critical issues in packaged food business. British Food Journal Business, 107, 760-780 .

Ampuero, O., \& Vila, N. (2006). Consumer perceptions of product packaging. Journal of Consumer Marketing, 23(2), 100-111.

Azad, N., Seyed Aliakbar, S.M., \& Kordalivand, N. (2012). Investigating effective factors on multimedia advertising: A case study of travel agencies. Management Science Letters, 2(1), 409416.

Azad, N., Rafiee, M., \& Hamdavipour, L. (2012). The role of children's food packaging characteristics on parent's purchasing decision. Management Science Letters, 2(3), 827-832.

Borin, N., Cerf, D.C., \& Krishnan, R. (2011). Consumer effects of environmental impact in product labeling. Journal of Consumer Marketing, 28(1), 76-86.

Boyce, J., Broz, C., \& Binkley, M. (2008). Consumer perspectives: take-out packaging and food safety. British Food Journal, 110, 819-828.

Butkevičiené, V., \& Stravinskiené, J., Rútelioné, A. (2008). Impact of consumer packaging communication on consumer decision making process. Economics of Engineering Decisions, 1(56), 57-65.

Hellström, D., \& Nilsson, F. (2011). Logistics-driven packaging innovation: a case study at IKEA. International Journal of Retail \& Distribution Management, 39(9), 638 - 657.

Howard, R., \& Moskowitz, T.M. (2010). Accelerating structured consumer-driven package design. Journal of Consumer Marketing, 27(2), 157 - 168.

Lee, S.G., \& Lye, S.W. (2003). Design for manual Packaging. International Journal of Physical Distribution and Logistics Management, 33(2), 163-189.

Marsh, K., \& Bugusu, B. (2007). Food packaging roles, materials, and environmental issues. Journal of Food Science, 72, 39-55.

Noorani, H.S., \& Setty, K. (2007). Three Steps for Successful implementation of Sales Portals in CPG companies. International Journal of Retail and Distribution Management, 35 , 746-749.

Olsson, A., Petterson, M., \& Johnson, G. (2004). Packaging demands in the food service industry. Food Service Technology, 4, 97-105.

Raghubir, P., \& Greenleaf, E.A. (2006). Ratios in Proportion: what should the shape of the package be?. Journal of Marketing, 70, 95-107.

Rundh, B. (2009). Packaging design: creating competitive advantage with product packaging. British Food Journal, 111(9), 988-1002.

Rundh, B. (2005). The Multi-faceted dimension of packaging: marketing logistic or marketing tool?. British Food Journal, 107(9), 670-84.

Silayoi, P., \& Speece, M. (2004). Packaging and purchase decisions: An exploratory study on the impact of involvement level and time pressure. British Food Journal, 106(8) , 607 - 628.

Silayoi, P., \& Speece, M. (2007). The importance of packaging attributes: a conjoint analysis approach. European Journal of Marketing, 41(11/12), 1495-1517. 
Vernuccio, M., Cozzolino, A., \& Michelini, L. (2010). An exploratory study of marketing, logistics, and ethics in packaging innovation. European Journal of Innovation Management, 13, 333-354.

Wansink, B. (1996). Can package size accelerate usage volume. Journal of Marketing, 60, 1-14 .

Wells, L., Farley, H., Armstrong, G.A. (2007). The importance of Packaging designing for Own-label food brands. International Journal of Retail and Distribution Management, 35, 677-690.

Yang, S., \& Priya, R. (2005). Can bottles speak volumes? The effect of package shape on how much to buy. Journal of Retailing, 81(4), 269-281. 